\title{
Evidence accumulating in support of cancer vaccines combined with chemotherapy: A pragmatic review of past and present efforts
}

\author{
JOSEPH G. SINKOVICS and JOSEPH C. HORVATH \\ Cancer Institute, St. Joseph's Hospital; Department of Clinical Microbiology and Immunology; \\ H.L. Moffitt Cancer Center, The University of South Florida College of Medicine, Tampa, FL, USA
}

Received May 15, 2006; Accepted June 19, 2006

\begin{abstract}
In the early 1970s supervised clinical trials were initiated at The University of Texas M.D. Anderson Hospital in Houston, TX, for the combination of viral oncolysate-based vaccines and contemporary chemotherapy for the treatment of patients with metastatic melanoma and sarcomas. This therapeutic approach was then generally considered to be inappropriate based on a widely held belief that the efficacy of cancer vaccines would be negated by the immunosuppressive effects of the chemotherapy. Not NCI grants, but institutional funds supported these clinical trials. These early clinical trials included in vitro tests for anti-tumor cell antibodies and cytotoxic lymphocytes both in autologous and allogeneic settings and showed that these faculties remained active even after chemotherapy. The contemporary reports of unexpectedly favorable clinical results are recited in this article. Despite these most promising results, support from federal granting agencies (the NIH/NCI) was repeatedly denied; these denials were based on the prevailing dogma that the two treatment modalities are expected to be antagonistic and not synergistic or not even additive. However, thirty years later, now in the new era of molecular medicine, a rapidly increasing number of peer-reviewed publications appear and offer convincing evidence that strongly substantiate the therapeutic value of combined cancer chemoimmunotherapy. The important provision is that the sequencing and dosing of the two major treatment modalities, the vaccination and the chemotherapy, are to be pre-tested and then the methodology is to be adhered to in the new clinical trials. New sophisticated experiments carried out in vitro and in vivo and subsequent clinical trials attest to the potential value of this combinatory approach and explain the underlying molecular mechanisms. This pragmatic review recapitulates the empirically administered earliest
\end{abstract}

Correspondence to: Professor J.G. Sinkovics, Cancer Institute, St. Joseph's Hospital, 3001 West Dr. Martin Luther King Jr. Boulevard, Tampa, FL 33607-6387, USA

E-mail: sinkovi.joseph@baycare.org

Key words: chemotherapy, immunotherapy, viral oncolysate cancer vaccines, FasL $\rightarrow$ FasR autocrine growth circuits clinical trials, and lists and interprets, in view of their molecular immunomodulatory effects, the exemplary new clinical trials.

\section{Contents}

1. Introduction: the earliest attempts were not appreciated

2. Intricate mechanisms of interaction

3. Some ideas for prospective current trials

4. Discussion

\section{Introduction: the earliest attempts were not appreciated}

Background. A leading tenet forcefully expounded in the 1970s presumed antagonism between cancer chemotherapy and immunotherapy. It was surmised that the immunosuppressive effects of chemotherapy would negate all benefits of active tumor-specific immunization with cancer vaccines. Remnants of this view persist (1-3). Grant applications repeatedly submitted in the mid-1970s from the Melanoma-Sarcoma Service, Department of Medicine, The University of Texas M.D. Anderson Hospital, Houston, Texas, to the USA NIH/ NCI for chemoimmunotherapy of metastatic melanomas and sarcomas were summarily (without a project site visit) rejected. These grant applications proposed contemporary chemotherapy courses to be given at 28 days intervals and immunotherapy to be administered late in the second or early in the third week postchemotherapy, when recovery of the blood count (especially that of the white blood cells) was occurring (Fig. 1). The immunotherapy consisted of autologous (preferred) or allogeneic tumor cell lysates obtained from primary or established tumor cell cultures $(4,5)$ infected with the live PR8 influenza A virus. This attenuated virus was oncolytic in vitro to the vast majority of human tumor cell cultures. Myxo(influenza) and paramyxo- (Newcastle disease) viruses were shown decades earlier to be oncolytic in ascites or solid tumors in mice and mice recovering tumor-free after dissolutions of large tumor burdens resisted newly inoculated native (not virusinfected) tumor cells of the same lines that were eliminated by viral oncolysis in vivo: thus, these mice acquired postoncolytic anti-tumor immunity $(6,7)$.

The 1970s were the times when nonspecific immunostimulation by live Corynebacterium parvum or Bacille 


\section{CHEMOIMMUNOTHERAPY FOR SARCOMAS}
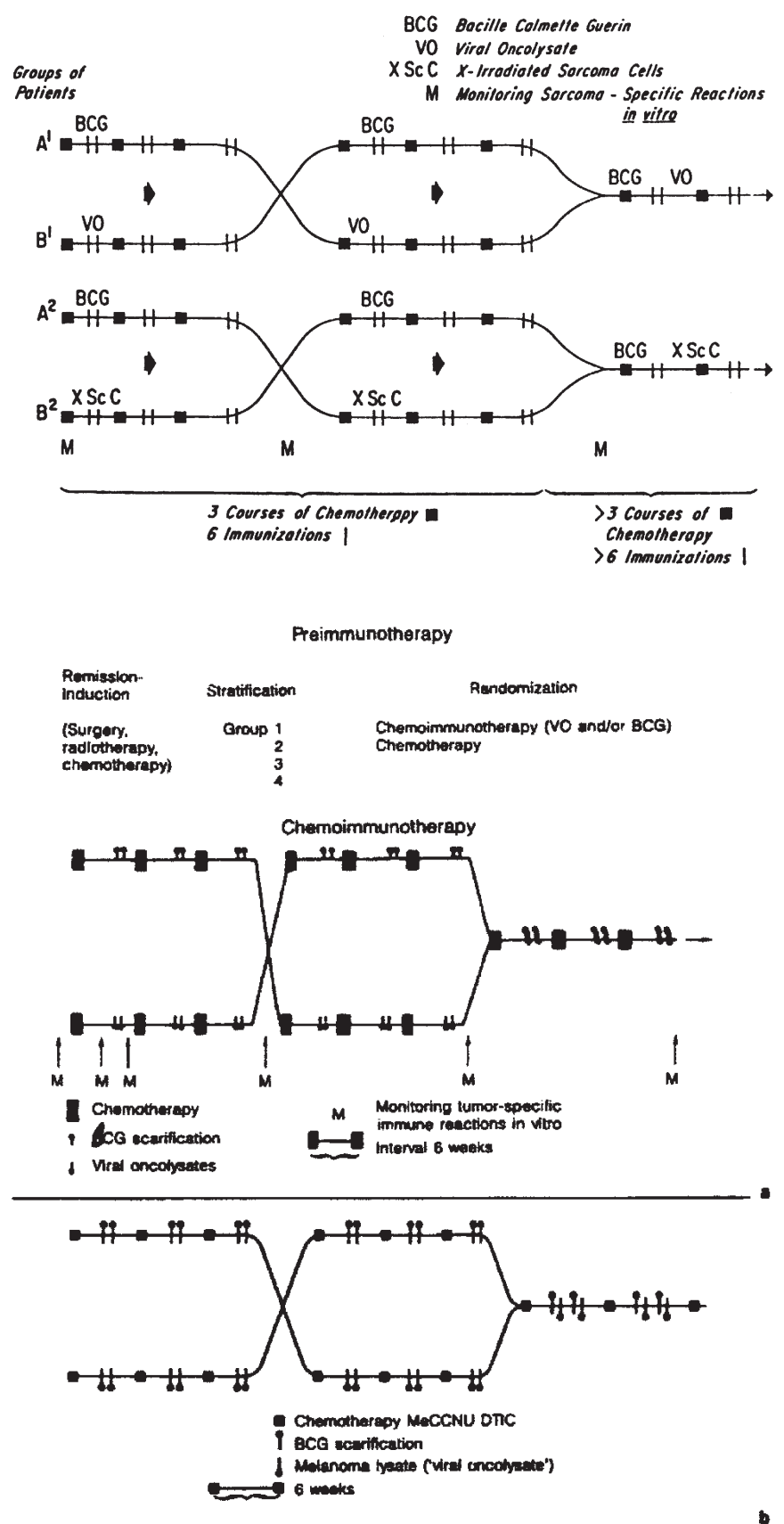

Figure 1. Schema of the first chemoimmunotherapy protocols for metastatic sarcomas and melanomas of adverse prognosis as approved by the Surveillance Committee of The University of Texas M.D. Anderson Hospital, Houston, TX, for implementation in the early 1970s (7).

Calmette-Guerin (BCG) vaccines were extensively tested and supported by the NCI. Accordingly, the grant proposals included BCG scarifications over the intra- or subcutaneous inoculation sites of the PR8 viral oncolysates (VO). Despite the denial of NCI support, the Surveillance Committee of M.D. Anderson Hospital allowed the commencement of these chemoimmunotherapy clinical trials, but requested that the PR8 virus be further attenuated (or even inactivated) by UV light in the final product. Thus, VO were checked by Dr Dieter Gröschel in the hospital's microbiology laboratories at the Clinical Pathology Department for bacterial contaminants and endotoxins (the limulus test) (8); and at the Section of Clinical Tumor Virology and Immunology, Department of Medicine, for remaining live tumor cells and live PR8 virus before inoculations into patients. The VO were free of live tumor cells, bacterial contaminants and endotoxins, but always contained small amounts of residual live PR8 virus (vide infra). Administration of $\mathrm{VO}$ was referred to as 'tumor-specific active immunization' but without the identification of 'tumor-specific antigens' in the VO preparations (9).

Clinical results. In a much abbreviated summary, chemoimmunotherapy thus administered appeared to induce better remission rates than chemotherapy alone, but this was not always, only occasionally, translated into a significantly prolonged survival. However, patients with hematogenous melanoma metastases at all sites except brain, who received VO, BCG and chemotherapy $(\mathrm{n}=11)$ lived 12.8 months versus 5.1 and 6.2 months survivals of patients treated with chemotherapy alone $(n=19)$ or with chemotherapy and BCG $(n=24)$, respectively $(10,11)$. While early relapses occurred in both groups of patients receiving standard chemotherapy and BCG without and with VO in addition, respectively, late relapses (after the third year of observation) were reduced to zero in two years of observation (1978-1980) in those patients with melanoma whose clinically positive regional lymph node metastases were surgically removed and who received thereafter treatment with $\mathrm{VO}, \mathrm{BCG}$ and chemotherapy $(\mathrm{n}=0 / 13)$. In contrast, late relapses continued in the group of patients treated postoperatively with chemotherapy and BCG $(n=7 / 17)$ (12).

Patients with metastatic sarcomas in complete remissions induced by adriamycin-based chemotherapy alone occasionally remained tumor-free for 3-5 years (13; Yap BS, et al, Proc 15th Ann Meet Am Soc Clin Oncol, New Orleans, LA, 20: 352, abs. 250, 1979). Patients with metastatic sarcomas of all clinical entities and all sites except brain were grouped together presuming that once sarcomas metastasized hematogenously, their prognosis was equally the worse. In this group of patients treatment with $\mathrm{VO}, \mathrm{BCG}$ and chemotherapy retarded progression of disease (32\% progressed in 6 months), whereas the progression rates of those patients who received chemotherapy only or chemotherapy and BCG were $72 \%$ and $53 \%$ in the same period of observation, respectively (Table I) (14-16). These patients were not 'prospectively randomized'; patients who did not yield live tumor samples for the laboratory (the Section of Clinical Tumor Virology and Immunology, Department of Medicine) for the preparation of autologous viral oncolysates were often enrolled in the control groups; patients were not stratified for sarcoma subtypes and prognostic factors; and in the pre-CT scan era subclinical residual disease could have been overlooked. For these reasons, this clinical trial was subjected to criticism and reservations, while its faultless conduct (in reference to 'individualized patient care') was recognized. However, its promising results should not be allowed to fall into oblivion.

Laboratory monitoring. In the era (late 1960s and early 1970s) when $\mathrm{B}$ and $\mathrm{T}$ lineages of lymphocytes were not clearly recognized as separate entities, the existence of NK cells was not yet even imagined, perforins and granzymes were not yet discovered, and the phenomena of programmed cell death 
Table I. Chemoimmunotherapy of patients with sarcomas at the Department of Medicine, M.D. Anderson Hospital, $1974-6$.

\begin{tabular}{|c|c|c|c|c|c|c|}
\hline Treatment & $\begin{array}{c}\text { Date of } \\
\text { evaluation }\end{array}$ & Patients $^{\mathrm{a}}$ & $\begin{array}{c}\text { Complete remission } \\
\text { (no evidence of disease) }\end{array}$ & $\begin{array}{l}\text { Partial remission } \\
\text { and stable }\end{array}$ & $\begin{array}{l}\text { Progression } \\
\quad \text { (death) }\end{array}$ & $\%$ Progressors \\
\hline \multirow[t]{2}{*}{ ChemoRx } & Oct '76 & 48 & 10 & 6 & 32 & 66 \\
\hline & Feb '77 & 49 & $10^{\mathrm{b}}$ & 3 & $36(17)$ & 72 \\
\hline ChemoRx & Oct '76 & 10 & 1 & 5 & 4 & 40 \\
\hline BCG & Feb '77 & 19 & $3^{c}$ & 6 & $10(4)$ & 53 \\
\hline ChemoRx & Oct '76 & 14 & 6 & 6 & 2 & 14 \\
\hline BCG, VO & Feb'77 & 19 & $4^{\mathrm{d}}$ & 9 & $6(3)$ & 32 \\
\hline
\end{tabular}

${ }^{a}$ In treatment more than 6 months. Rendered NED surgically ${ }^{\mathrm{b}} 5,{ }^{\mathrm{c}} 3,{ }^{\mathrm{d}} 3$. ChemoRx: vincristine, cyclophosphamide, adriamycin/actinomycin D, dimethyl triazeno imidazole carboxamide, days 1-5 Q28 days. ImmunoRx: BCG (Chicago) and sarcoma viral oncolysates, days 17 and 24. Reproduction of Table II from the Chicago Symposium, February 24-25, 1977 sponsored by the University of Illinois at the Medical Center and the Illinois Cancer Council, Chicago, IL; from The Franklin Institute Press, Philadelphia, PA, with permission. Library of Congress Catalog Card \#77-777-7. Patients with metastatic sarcomas were treated and evaluated at the Melanoma-Sarcoma Service, Department of Medicine, The University of Texas M.D. Anderson Hospital, Houston, TX, by fellows and resident physicians supervised by staff physicians Drs Carl Plager and Joseph Sinkovics (16).

(apoptosis) were not yet elaborated on, at the Section of Clinical Tumor Virology and Immunology, Department of Medicine, small compact lymphocytes (much later recognized as immune $\mathrm{T}$ cells) were already captured in the act of attacking and killing autologous tumor cells; and large granular lymphocytes (much later recognized as NK cells) were photographed as they killed allogeneic tumor cells either by 'nuclear clumping' or by cytoplasmic lysis (plate of Fig. 2) (17-19). Lymphocytemediated cytotoxicity to tumor cells in patients who received chemotherapy, the appearance of 'serum factors' (antibodies) antagonizing ('blocking') or intensifying ('unblocking') the cytotoxicity of lymphocytes on tumor cells and the delayedtype skin reactions at the sites of VO inoculations (20) (administered intracutaneously without overscarifications of BCG) indicated that the postulated immunosuppressive effects of chemotherapy were not fully operational. The sites of intraor subcutaneous VO administrations with or without BCG overscarifications were not biopsied; thus the cellular reactions induced (granulocytes, macrophages, $\mathrm{B}$ and $\mathrm{T}$ classes of lymphocytes and the as yet undiscovered dendritic cells or cytokines-chemokines) could only be surmised. Further, some chemotherapeuticals (cytosine arabinoside) eliminated the production of blocking serum factors (antibodies) antagonizing the cytotoxicity of small compact lymphocytes on autologous tumor cells (21). The postchemotherapy 'rebound phenomenon' (22) of leukocyte counts argued for short-lasting and reversible immunosuppressive effects of chemotherapy.

These earliest attempts at combining chemotherapy with 'tumor-specific' vaccination and monitoring the results clinically and in vitro, indeed were not appreciated in their time; nevertheless they should be remembered in the era of molecular immunology as justifications emerge for this concept. The complex mechanisms of these interactions were recently reviewed $(23,24)$; this present article elaborates further on evidence-based arguments in favor of chemotherapycombined anti-tumor vaccination.

\section{Intricate mechanisms of interaction}

Chemotherapy-resistant tumor cells. Chemotherapy-resistant tumor cells exposed to chemotherapeuticals either undergo a protracted dying process or remain alive and respond with a variety of biological changes. Those tumor cells (melanoma and kidney carcinoma) that withheld MHC expression will now under the effect of 5-aza-2 deoxycytidine re-express MHC (25). Tumor cells presenting antigenic peptides in the groves of their MHC class I do this without the expression of costimulatory molecules B7-1,2 and the antigens thus presented would elicit a tolerogenic rather than an immunogenic response in the host; under the effect of melphalan or mitomycin C, reexpression of the costimulatory molecules will occur and the anti-tumor response becomes rather immunogenic (Th1-like) than tolerogenic (23).

Treatment of breast cancer cells with paclitaxel induces a dendritic cell-mediated immune Th1 cell response (26). In this case dendritic cell (DC) maturation and antigen-presenting activity is induced by the stimulation of innate Toll receptors of the DC (27); paclitaxel interacts with lipopolysacchariderecognizing ancient receptors. Patients with stages II-III pancreatic carcinoma are treated with pancreaticoduodenectomy, thus reducing their tumor burden (cytoreductive surgery). These patients received the first dose an allogeneic GM-CSFsecreting pancreatic cancer cell vaccine immediately postoperatively; thereafter for 6 months a combined regimen of radiation and chemotherapy was given. At this point tumor-free patients failed to show the presence of mesothelin-reactive immune $\mathrm{T}$ cells; however, re-administration of the vaccine induced both delayed hypersensitivity skin reactions to autologous tumor cell lysates and mobilization of mesothelinreactive $\mathrm{CD}^{+}{ }^{+}$immune $\mathrm{T}$ cells in some of the patients $(23,28)$. The interpretation of this clinical trial is that vaccination could overcome a chemotherapy-induced suppression of anti-tumor reactivity in patients with minimal residual tumor burden. 


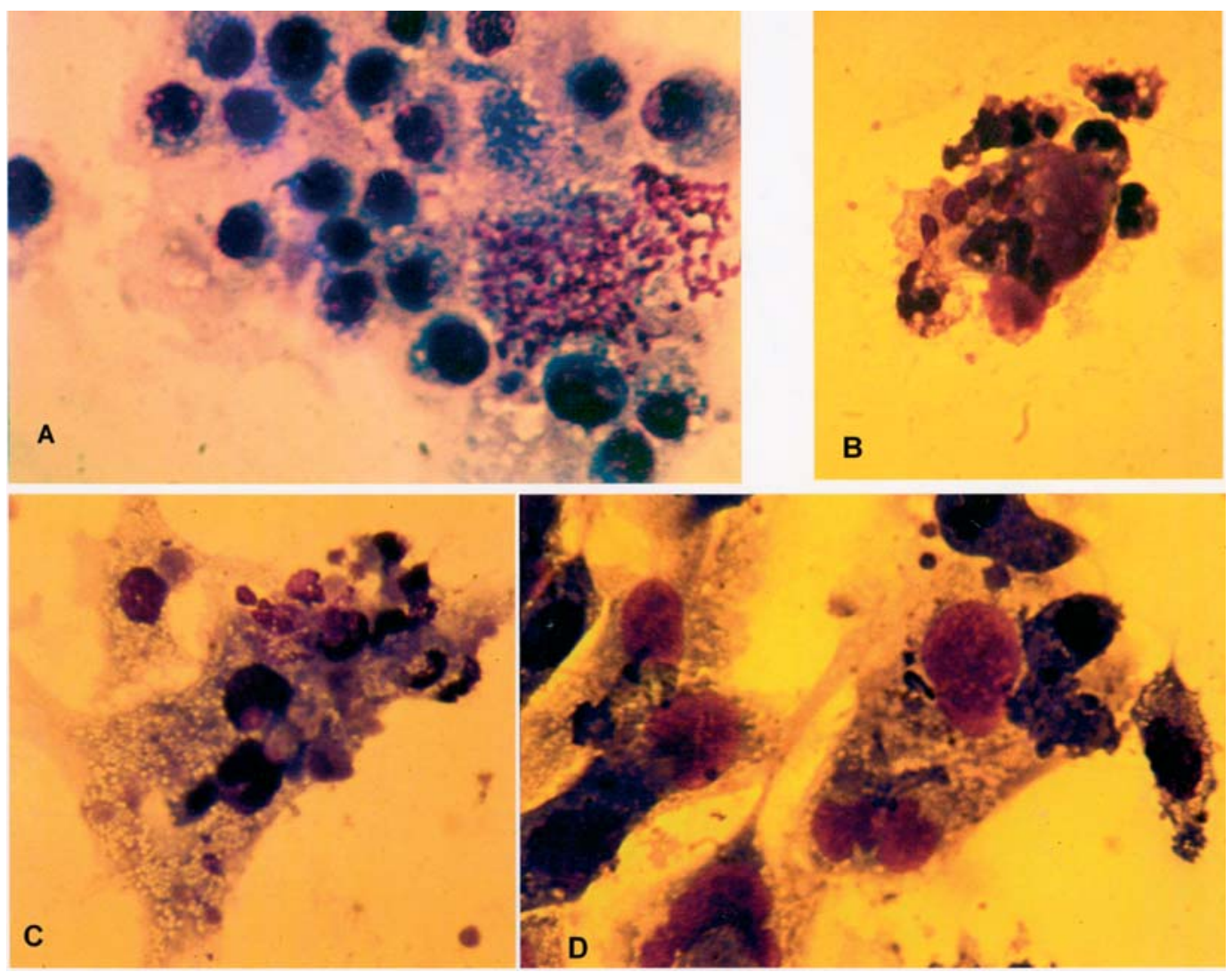

Figure 2. (Plate) A, Lymphoma cell line \#778 established from male patient HF (MDAH \#54537) in 1966 by J.G. Sinkovics consisted of single and large multinucleated cells produced by cell fusions. The large multinucleated cells when exposed to the patient's purified peripheral blood lymphocytes either resisted the lymphocytes or died by 'nuclear clumping' and dissolution of the cytoplasm as shown. The attacker cells were the 'small compact lymphocytes' (later recognized to be 'immune T cells') (19). Ectachrome, January 25, 1967. B, Rhabdomyosarcoma patient MMM's (MDAH \#79161) autologous 'small compact lymphocytes' attack a rhabdomyosarcoma cell which undergoes cytoplasmic lysis, while some of the attacker lymphocytes show signs of 'nuclear clumping' in an era when tumor cell counterattack by FasL $\rightarrow$ FasR positive host lymphocytes was not yet known. Experiment \#2494, Oct 2, 1971 (19). C, Patient LN (MDAH \#90641) with metastatic liposarcoma received chemoimmunotherapy and achieved complete remission; immunotherapy consisted of vaccination with an allogeneic sarcoma VO preparation of cell line \#3743 (4) and BCG. He mobilized 'small compact' and 'large granular' (later: NK cells) lymphocytes to attack and lyse in vitro the cells of allogeneic sarcoma cell line \#3743. Experiment \#2992, April 14, 1972 (9,14,19). D, Healthy donor laboratory technologist JC's lymphocytes interacting with Trujillo's T2 fibrosarcoma cells (protocol \#2117): are either small compact lymphocytes in early blastic transformation or large granular lymphocytes (later: NK cells). Shown in the cited reference as graph 3B from 1970 (but not as a microphotograph) (19).

Some tumor cells acquire immunoresistance by the expression of Fas ligand (CD95L) and kill Fas receptorpositive immune T cells of the host (29). Paradoxically, some melanoma cells expropriate the FasL $\rightarrow$ FasR system for an autocrine growth circuit (30). Fas-ligand-resistant melanoma cells were rendered in vitro susceptible to FasL- and granzymeinduced apoptosis by pretreatment with 5-fluorouracil or dacarbazine (31). Vice versa, FasL-sensitive sarcoma cells are also susceptible to chemotherapy (32).

Tumor cells undergoing genotoxic stress and stalled DNA replication express ligands that are members of the MIC (MHC class I chain-related molecules) and RAET1 families. The human retinoic acid early transcripts, the RAET1 family, consists of the ULBP-related cluster of genes and transcripts from chromosome 6p24.2-q25.3 and it is referred to as ULBPs, the UL16 glycoproteins of human cytomegalovirus. The ligands RAET1E/ULBP4 are recognized by the NK cell receptor NKG2D, the major 'natural cytotoxicty receptor'. These receptors are also expressed by subsets of $\gamma / \delta$ NKT cells and $\mathrm{CD} 8^{+}$activated immune $\alpha / \beta$ T cells. While these NK and immune T cells kill stressed tumor cells, this type of lymphocyte-mediated cytotoxicity is counteracted by soluble MICA and transforming growth factor- $\beta$ released from the cell or by
IFN- $\gamma$ which downregulates NKG2D receptor expression in NK cells $(33,34)$.

Chemotherapy-sensitive tumor cells. Chemotherapy-sensitive tumor cells die apoptotic or autophagic deaths. Mature DC express tumor cell antigens either by intracellularly processing them after phagocytizing of, or accomplishing fusion with, dead tumor cells, or by extrinsically loading tumor cell-derived free peptides into their MHC for presentation to $\mathrm{T}$ or to certain subclasses of natural killer (NK) cells through the immunological synapse. However, effective presentation of tumor antigens to reactive lymphocytes is very complicated. Heatshock proteins are molecular chaperons that transfer the antigens from tumor cell lysates to DC (35). Mature proteins, peptides and incomplete ribosomal products are processed differently for the MHC class I pathway. The primary signals coming from immature DC are 'non-priming' in order to maintain self-tolerance. These signals are so overwhelming that they can block lymphocyte-mediated cytotoxicity to cells expressing a viral (influenza virus HA) antigen (36). In this system co-production of IL-12 or the anti-CD40 antibody can break the tolerance and induce cytotoxic effector reactions of immune $\mathrm{CD}^{+}$lymphocytes. Mesothelioma cells transfected to 
express the HA antigen also induce a blunted cytotoxic T cell(CTL-) mediated reaction (37).

Chemotherapy (or radiofrequency-induced tumor ablation like in liver metastases) providing large numbers of apoptotic tumor cells and molecular mediators inducing DC maturation (GM-CSF, type I interferons, IL-12) 'cranks the immunology engine' and acts as an in vivo (in the patient) tumor vaccine (38). Indeed, IFN- $\alpha$ induces DC maturation and B7.2 expression (39). IFN- $\alpha$ enhanced the efficacy of a GM-CSFsecreting cancer vaccine (B16.GM) in mice (40).

When tumor cells express carcinoembryonic antigens, the host responds with a blunted immune reaction that suppresses the expression of these target antigens in the tumor cells without cell kill; thus vaccines aimed at inducing immune reactions against CEA may fail. However, in colon and breast carcinoma cells, 5-flurouracil induces the re-expression of CEA and renders these tumor cells susceptible to HLA-A*02.01restricted CEA peptide-specific cytotoxic immune $\mathrm{T}$ cells (41). The interpretation is that chemotherapy and anti-CEA vaccinations act synergistically in this system.

In human breast cancer, the monoclonal antibody trastuzumab very significantly improves the results of chemotherapy either in the adjuvant setting or when applied against metastatic disease and its mechanisms of action include NK cell activation through the ADCC pathway. The amplified or mutated HER2/neu oncogene when expressed in breast cancer cells is immunogenic in its host; indeed there are efforts to intensify anti-HER2/neu cell- and antibody-mediated immune reactions of patients by vaccinations against the oncogenic product proteins. While trastuzumab does, HER2/neu peptide epitope-generated T cells fail to, attack HER2/neu $u^{+}$tumor cells (42). Whereas paclitaxel treatment of patients with breast cancer induces immune $\mathrm{T}$ cells that infiltrate the tumor and contribute to the induction of complete remissions (26). The LPS-mimetic activity of paclitaxel activates innate immune reactions $(26,27,43)$, that is innate reactions are translated by DC into adaptive immunity resulting in effective immune $\mathrm{T}$ cell generation.

Murine models provide some guidance toward human clinical trials. In rats, tolerance to HER2/neu can be broken by vaccination against the oncogene protein and the vaccine synergizes with chemotherapy. The target of a GM-CSFsecreting anti-HER2/neu vaccine is the epitope $\mathrm{RNEU}_{420-429}$ within the protein antigen. The vaccine induces both antibody and immune $\mathrm{CD} 8^{+} \mathrm{T}$ cell responses against this target. In contrast, in MMTV-neu-transgenic mice tolerance to HER2/ neu prevails despite vaccination. However, treatment of these mice with low dose cyclophosphamide or paclitaxel 1 day before vaccination resulted in a vigorous immune response to the oncogenic protein. Low dose doxorubicin given 7 days later further intensified this immune response; it was shown that doxorubicin given 3-5 days before vaccination induces the generation of specific immune T cells. High dose chemotherapy with these agents or different time schedules of vaccine and chemotherapy administrations or certain other chemotherapeutic agents (gemcitabine) negated the efficacy of the vaccine (44-47). Complete remissions and cures occurred only in those mice, which mobilized $\mathrm{RNEU}_{420-429} \mathrm{CD}^{+}$ immune $\mathrm{T}$ cells (45-47). In these systems the contribution of cyclophosphamide is the one best understood; it abrogates
$\mathrm{T}_{\mathrm{REG}}$ activity (vide infra), induces type I interferons and promotes Th1-type immunity and the generation of CD44hi T memory cells (48). In other murine tumor (colon carcinoma) models, cyclophosphamide excelled to be the most effective chemotherapeutical in promoting the efficacy of the GM-CSFsecreting CT26 vaccine (49). It is a good question how much better the results of past clinical trials such as the one with colon cancer vaccine in stages II and III of the disease (50) would have been, if judicious coadministration of chemotherapeuticals were included.

Prostate cancer vaccines in clinical trials consist of recombinant vaccinia virus expressing prostate-specific antigen gene rV-PSA and the co-stimulatory gene rV-B7.1; and recombinant fowl pox virus containing the PSA gene (fF-PSA). These vaccines are co-administered with granulocyte macrophage colony-stimulating factor. The vaccines generate PSA-specific T cell response. Patients progressing while vaccinated received docetaxel chemotherapy and experienced 6.1 months progression-free survival; not pre-vaccinated historical control patients with progressive disease receiving docetaxel experienced 3.7 months progression-free survival. Immune $\mathrm{T}$ cell responses were not blunted by docetaxel administration (51).

The antigenicity of mutated oncogenes and fusion oncoproteins. Some proto-oncogenes/oncogenes (survivin, telomerase) $(52,53)$ that also elicit a blunted $\mathrm{T}$ cell-mediated immune reaction in the tumor-bearing host are incorporated in vaccines (adenoviral vectors, other oncolytic viruses) (7), in order to intensify the naturally weak immune responses of the host; indeed, co-administation of selected and properly timed chemotherapeutical agents are expected to yield evidence for enhancement of the efficacy both of these vaccines and of oncolytic viruses (7). The tumor suppressor gene $\mathrm{p} 53$, the 'guardian of the genome', is frequently mutated or neutralized by fusion with cellular (MDM) or DNA oncogenic viral (SV40 large T antigen, papillomaviral E6, adenoviral E1B, Epstein-Barr viral EBNA-5) oncoproteins, or is eliminated by ubiquitination in proteasomes in tumor cells. Tumor cells without functional wild-type p53 escape apoptotic death. While the mutated p53 gains longevity (prolonged half-life of its protein product in contrast of the short half-life of the wildtype gene product protein), it induces the generation of antip53-reactive immune T cells that can kill tumor cells harboring mutated p53 proteins; however, in the tumor-bearing patients this reaction is blunted.

Patients with small cell undifferentiated lung cancer (SCLC) were vaccinated at the Moffitt Cancer Center in Tampa, FL with autologous DC transduced by an adenoviral vector (Ad-p53) with full-length wild-type p53 genome. The disease progressed in most of the vaccinated patients and stabilized in a few patients; clinical tumor response to the vaccine occurred only in one patient. Most vaccinated patients generated p53 protein-specific T cells and anti-adenoviral antibodies; these immune reactions were antagonized by immature myeloid cells. Upon postvaccination, standard second line chemotherapy (cis- or carboplatin, etoposide, irinotecan) induced an unexpectedly high (62\%) clinically documented tumor response $(\mathrm{CR} / \mathrm{PR})$ in those patients who previously were deemed to be chemotherapy- (platinol-) resistant (54). In 
another clinical trial, those patients with SCLC who developed immune reactions to the universal tumor antigen CYP1B1 exhibited an unexpectedly high response to second line chemotherapy (55). In another pioneering Canadian clinical trial, patients $(n=33)$ with early stages of lung cancer of various histological subtypes received postoperatively high dose methotrexate with leucovorin rescue; or allogeneic lung cancer-derived solubilized antigens in Freund's adjuvant; or these two modalities of treatment together. Patients who received methotrexate performed better than those who received the vaccine. However, patients receiving 'immunochemotherapy' remained free of relapses in highest numbers and for the longest time (56).

Autologous DC pulsed with glioblastoma multiformederived peptides induced immune $\mathrm{T}$ cells ('recent thymic emigrants') that infiltrated residual tumors. Vaccinated patients upon receiving standard chemotherapy (temozolomide, irinotecan, imatinib mesylate, thalidomide, etoposide, procarbazine, vincristine and nitrosourea) frequently responded with unusually durable and $>50 \%$ tumor size regressions $(57,58)$.

The extraordinary influence of the stroma. Eva Klein, the editor of Seminars in Cancer Biology, recognized the extraordinary influence of the stroma in the tumor's microenvironment in promoting or abrogating tumor growth $(59,60)$. There is a discrepancy between the high susceptibility of tumor cells exiled into xenografts (or anoikis) to chemical or biological agents, which, when tested in the tumor's natural host, fail to eradicate the tumor (61). In addition to anti-endothelial cell monoclonal antibodies, vaccines and small molecular inhibitors of neoangiogenesis, indeed chemotherapeutical agents may be found that suppress many other tumor-promoting activities of the stroma and thus enhance the efficacy of co-administered tumor vaccines.

Immunosuppressive evasive maneuvers. Immunosuppressive evasive maneuvers are shared between the fetus and especially its placenta and malignant tumors (19). Regulatory T cells $\left(\mathrm{T}_{\mathrm{REG}}\right)$, the physiological guardians against autoimmunity and the supervisors of tolerance maintenance toward 'self', protect both the fetus against the attack of maternal $\mathrm{T}$ cells on paternal antigenic epitopes expressed by fetal cells and the tumor against immune $\mathrm{T}$ cells of its host.

In the ascites of patients with ovarian carcinoma $T_{R E G}$ cells are $\mathrm{CD}^{+}{ }^{+} \mathrm{CD} 25^{+}(\mathrm{IL}-2 \mathrm{R} \alpha$ chain $) \mathrm{FOXP} 3^{+} \mathrm{CCR} 4^{+}(\mathrm{CCL} 22 \mathrm{R})$ $\mathrm{T}$ cells that undergo clonal expansion in response to IL-2 and migrate in response to chemokine CCL22. Tumor cells and tumor-infiltrating macrophages overexpress CCL22 mRNA. Epidermal growth factor receptor (EGF-R) HER2/neu+ tumors attract most $\mathrm{T}_{\mathrm{REG}}$. In the tumor's environment $\mathrm{T}_{\mathrm{REG}}$ eliminate CTL mobilized by the host against its tumor. The monoclonal antibody denileukin diftitox aimed at the $\mathrm{CD} 25^{+}$malignant $\mathrm{T}$ cells may (or may not) be able to eliminate $\mathrm{T}_{\mathrm{REG}}(62,63)$. The case history of a patient with a HER $2 / n e u^{+}$ovarian carcinoma was presented at the 5th International Conference on Ovarian Cancer in Houston, TX (Sinkovics JG, et al, abs. 17, 2004). The chemotherapy-resistant tumor disseminated in her abdomen at which point she received adoptive immunotherapy intravenously and repeatedly with lymphocytes extracted from her ascites and expanded in vitro; large granular lymphocytes (not characterized further but believed to be NK cells) dominated the infused cell population. She received 5-10 million units of IL-2 subcutaneously and developed severe psychosis and refused further therapy with IL-2. She however entered remission and responded further to Doxil to which she displayed resistance prior to adoptive immunotherapy. The interpretation was that IL-2 might also have promoted the expansion of $\mathrm{T}_{\mathrm{REG}}$ but that adoptively administered $\mathrm{NK}$ cells may be resistant to elimination by $\mathrm{T}_{\mathrm{REG}}$.

The tryptophan catalytic enzyme indolamine-2,3 dioxygenase (IDO) renders $\mathrm{T}$ cell clones expanding in response to an antigen ineffective; these tryptophan-dependent $\mathrm{T}$ cells either become tolerogenic or die apoptotic deaths. Both the fetal placenta and growing tumors overexpress IDO (64). The IDO inhibitor 1-methyl-tryptophan reverses the process and restores reactivity of expanding $\mathrm{T}$ cell clones with resulting abortion in the case of the fetus, or rejection in the case of the tumor. Against MMTVneu murine breast carcinomas, the combination of 1-methyl-tryptophan and chemotherapy acted synergistically promoting immune $\mathrm{T}$ cell-mediated anti-tumor reactions (65).

In a plenary lecture given on chemoimmunotherapy in 1978 at the 12th International Cancer Congress in Buenos Aires, Argentina, an experiment was presented in which mice inoculated by fetal cells allowed the unusually rapid growth of a lymphoma; this tumor was moderately sensitive to cyclophosphamide. However, its rapidly growing variant in fetal cell-pretreated mice showed increased susceptibility to low dose cyclophosphamide. The interpretation was offered that carcinoembryonic antigens released by the fetal cells induced clonal expansion of suppressor cells akin to the feto-maternal setting and in the tumor-bearing host and that these clones were eradicated by cyclophosphamide allowing immune reactivities to be mobilized unopposed (11). At the International Meeting on Cancer Vaccines held in Rome, Italy, in 2004, a session was devoted to the 'learning how to overcome the suppressor activity of regulatory T cells' (66). Low doses of cyclophosphamide given prior to tumor vaccine administration for $\mathrm{T}$ cell 'priming' abrogated immune tolerance by eliminating $\mathrm{T}_{\text {REG }}(23)$.

When it comes to the balance of tumor-enhancing antibodies versus CTL, recently gemcitabine was shown to suppress antibody production thus allowing unopposed flow of cell-mediated immunity (44). Long time ago, cytosine arabinoside was shown to suppress 'blocking factors' in tumor-bearing patients (antibodies antagonizing cytotoxic immune $\mathrm{T}$ cells by covering epitopes to be targeted by $\mathrm{T}$ cells), thus allowing CTL to exert their effect in in vitro assays (21).

\section{Some ideas for prospective current trials}

Melanoma. At the authors' Institution, patients with melanoma of adverse prognosis in stages I, II, and III of the disease (in this latter stage: patients with regional lymph node metastases who refused or could not tolerate the postoperative administration of the Schering IFN- $\alpha 2 b$ protocol) received the Emory University (Dr Wm. Cassel's) Newcastle disease virus (NDV) oncolysate (VO) vaccine $(67,68)$. In the past fourteen years, 53 patients with melanoma were vaccinated 


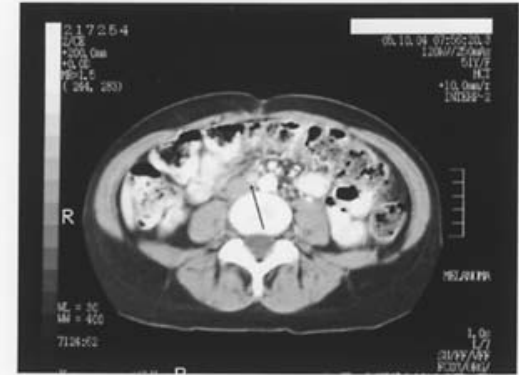

Aa

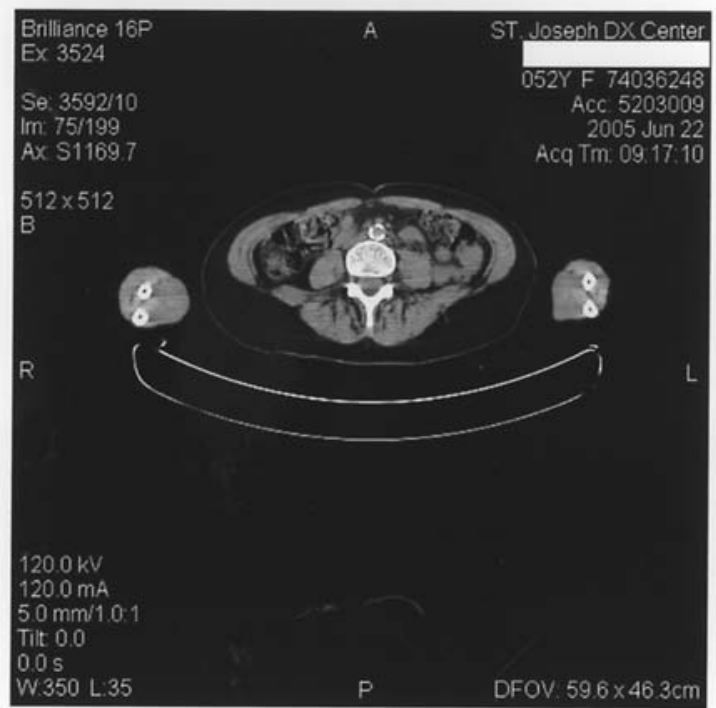

Ba

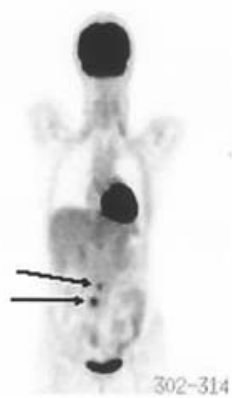

Ab

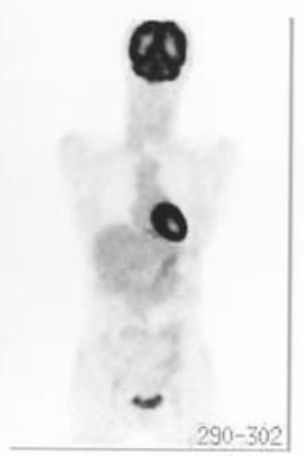

Bb

Figure 3. Female patient JM with ulcerating deep melanoma on her left chick received postoperatively autologous NDV oncolysate vaccine in 2003 and relapsed with retroperitoneal lymphadenopathy in 2004. Repeated CT and PET scans showed enlarging retroperitoneal lymph nodes. After 3 courses of biochemotherapy both CT and PET scans became negative and the complete remission remains sustained early in 2006. Aa, Enlarged retroperitoneal lymph nodes (arrow) by computed tomograms (CT) and Ab, by positive positron-emission tomogram (PET) in mid-2004. Ba and Bb, Complete regression of enlarged lymph nodes with negative CT and PET scans in December 2004 after three courses of biochemotherapy.

with NDV oncolysates. Not only patients who were surgically rendered tumor-free, but also patients in early postoperative relapse were accepted for vaccination. Patients experiencing early relapse often failed to enter remissions while receiving the vaccine, but some of these patients upon biochemotherapy with or without adoptive lymphocyte therapy added (19), showed unexpectedly long duration of their partial responses or stabilizations of their metastatic disease. A tabulated account of these patients is now being prepared. A recently treated patient is selected for presentation here.

This exemplary patient is JM, a 50 years old Caucasian woman with ulcerating melanoma on her left cheek. A dermatologist performed a 'shave biopsy' on January 2003 (a procedure these authors are strongly opposed to) and thus diagnosed a malignant melanoma Clark level III and Breslow thickness $\geq 0.9 \mathrm{~mm}$. A plastic surgeon performed a wide excision on March 11, 2003 and found that the lesion penetrated vertically downward to Clark level V. However, sentinel node biopsies revealed 5 negative nodes. After surgical removal of all gross disease, the patient received allogeneic viral (NDV) oncolysate vaccine with IFN- $\alpha 2 b$; the vaccine was given subcutaneously on a day in midweek and 5 million units of interferon
(IFN- $\alpha 2 b$, Intron, Schering) were given subcutaneously for five days from Monday to Friday on that week. The patient received 16 such vaccinations from April 28, 2003 to April 16,2004 . She remained free of locoregional relapse, but in April 2004 she was found with soft freely rolling non-tender small marble-sized bilateral axillary lymph nodes with a low SUV uptake of 1.8 on PET scan, thus interpreted as 'reactive lymph nodes'. Soon thereafter CT and PET scans revealed retroperitoneal lymph nodes situated in between the inferior vena cava and the aorta. The patient declined biopsy and biochemotherapy. By August 2004 the lymph nodes increased in size and intensified their SUV uptake on PET scan, while the axillary nodes did not stain anymore. CT and NMR images of the thorax and brain were negative, respectively. Then the patient accepted and received the M.D. Anderson Hospital biochemotherapy regimen consisting of intravenous vinblastine, cisplatin, dacarbazine and IL-2; since she received interferon while she was vaccinated, interferon was left out of the protocol. She received 3 courses of biochemotherapy in October, November and December 2004 and was re-staged by CT/PET scans in December 2004: by then all detectable disease resolved and she entered complete remission (Fig. 3). 


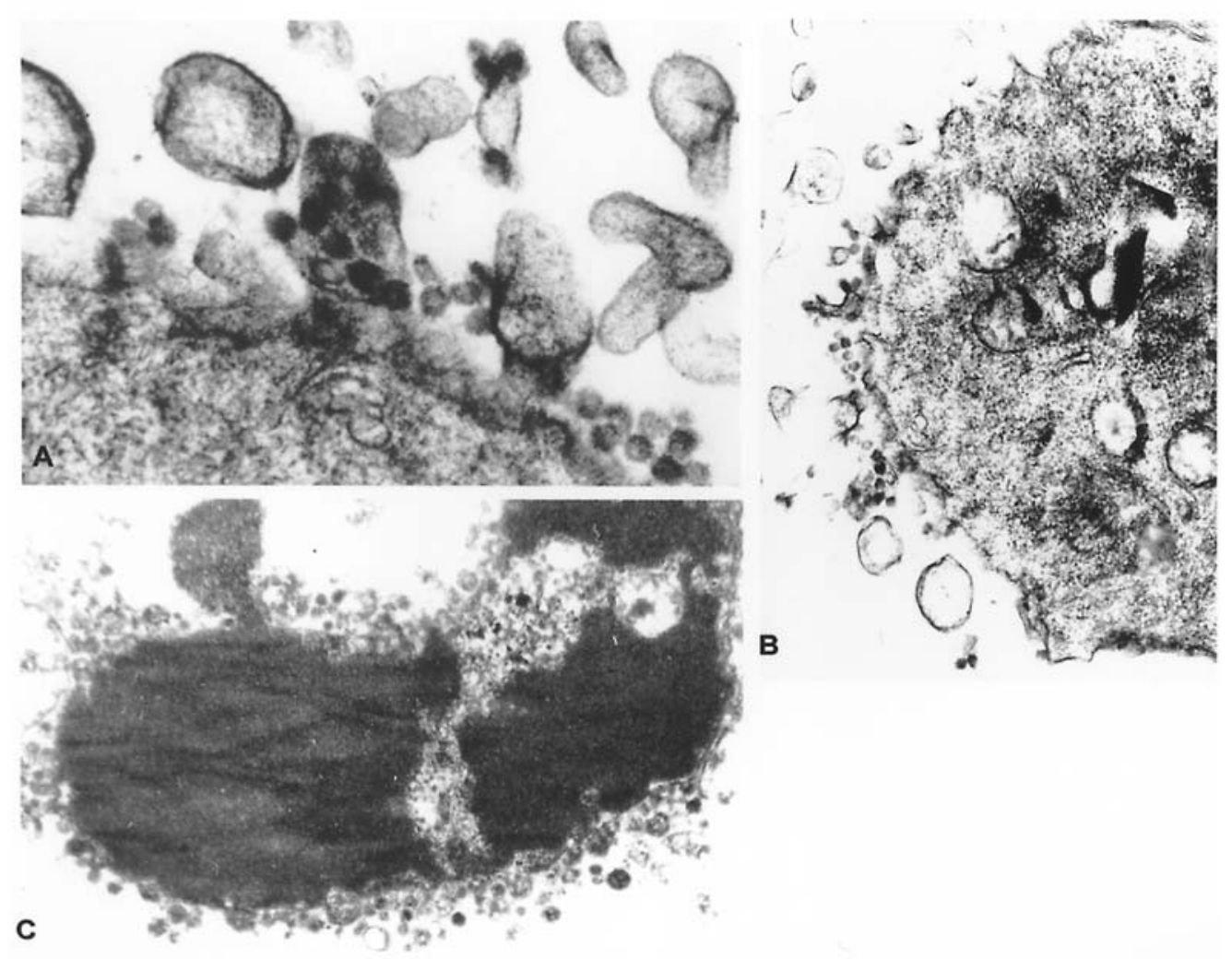

Figure 4. Human sarcoma cell lines (4) undergo oncolysis after infection with PR8 virus. A, Ewing's sarcoma cell line \#1846; B, Chondrosarcoma cell line \#2454; C, Cystosarcoma phylloides cell line \#3743. Transmission electron microscopy from the early 1970s (Györkey F and Sinkovics JG, unpublished data).

She received biochemotherapy course 4 in January 2005, but could not go through course 5 in February 2005 due to IL-2 toxicity, which was reversible after discontinuation of the protocol. Off treatment, she remains in complete remission by CT/PET scan as recently as February 2006; next scans are due in mid-2006. Her complete remission ensuing promptly and remaining durable can be attributed to the additive effect of the melanoma vaccine and subsequent chemotherapy.

Patients treated with NDV oncolysate vaccines at Emory University in the last three decades for grossly positive, but surgically resected regional lymph node metastases, show an unusually long tumor-free survival (67). However, relapsed patients in this cohort should be offered from single agent (DTIC = dacarbazine) to combination chemotherapy; the same principle should be applied in cases of relapse after the receipt of the Canvaxin (Morton) or Melacin (Mitchell) or other melanoma vaccines.

Viral oncolysate cancer vaccines are not widely recognized because they were not tested in prospectively randomized clinical trials and have not been fitted into the era of molecular immunology. The original human VO vaccine developed in the 1970s at M.D. Anderson Hospital $(5,15)$ utilized the attenuated PR8 influenza A virus for in vitro oncolysis; despite UVirradiation, live virus always remained in the end product oncolysates (Horvath JC, et al, Proc 86th Annual Meeting Am Assoc Cancer Res, Toronto, Canada, 36: 439, abs. 2619, 1995). This virus was highly oncolytic in vitro to a variety of human tumor cells (melanoma, sarcoma, kidney and ovarian carcinoma) (Fig. 4); tumor cell deaths occurred either by 'nuclear clumping' or by cytoplasmic disintegration (not recognized in the 1970s to be apoptosis or autophagy). However, the extraordinary variability of the influenza viral genome (its propensity to recombine between different viral strains encountering one another in the same host) (Fig. 5) (69), in contrast to the stability of the NDV genome; and the most promising results reported from Emory University, Atlanta, GA (67), commanded a switch from influenza to NDV for oncolysate preparation.

Vesicular stomatitis virus (VSV) was another early consideration for the preparation of viral oncolysates, because of its propensity to fuse tumor cells and thus escape virus neutralizing antibodies before the disintegration of tumor cell syncytia (Fig. 6) (70,71). These phenomena are now being rediscovered and are superbly elaborated on as a form of nonapoptotic 'bio-energic tumor cell death' (72-74). 'Syncytiosomes' evoke first an innate immune reaction in activating cytotoxic macrophages and NK cells and present ('load') tumor antigens to DC, which then elicit adaptive immune reactions by mobilizing cytotoxic immune T cells. In Ottawa, Canada and in Miami, FL, VSV has become a prime candidate oncolytic virus or anti-tumor $\mathrm{VO}$ vaccine or a vector for gene therapy (reviewed in detail) (7).

However, the combination of oncolytic viruses with chemotherapy, attractive as it seems, may impose unexpected risks. If an attenuated virus is genetically incapacitated to invade its host and its growth is limited to tumor tissue (and NDV is 


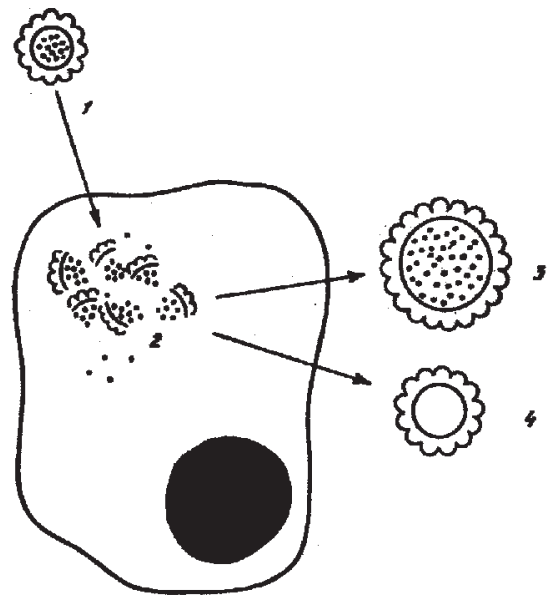

A
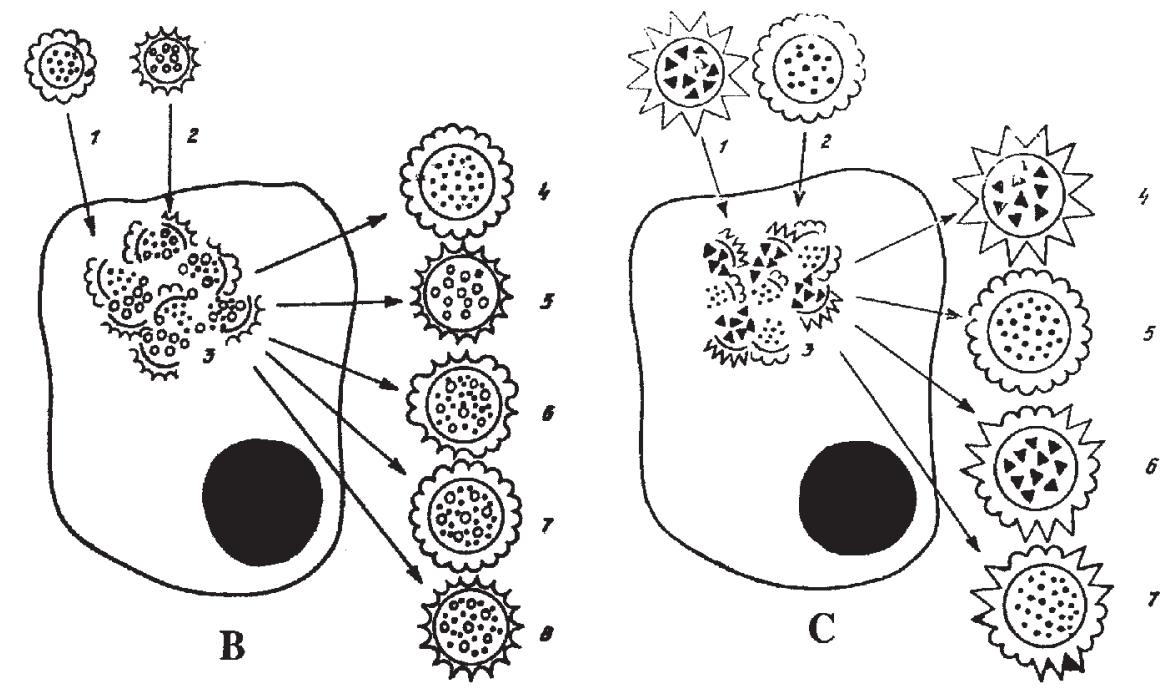

Figure 5. Inluenza A virus recombinations as depicted in the senior author's monograph in 1955 (69). A, The eclipse phenomenon and complete infectious, and incomplete non-infectious virus particle formation. B, 'Genotypenvermischung': genetic recombination of two different influenza A virus particles co-infecting the same cell. C, 'Phenotypen-vermischung': phenotype exchange between two influenza A virus particles co-infecting the same cell (69).
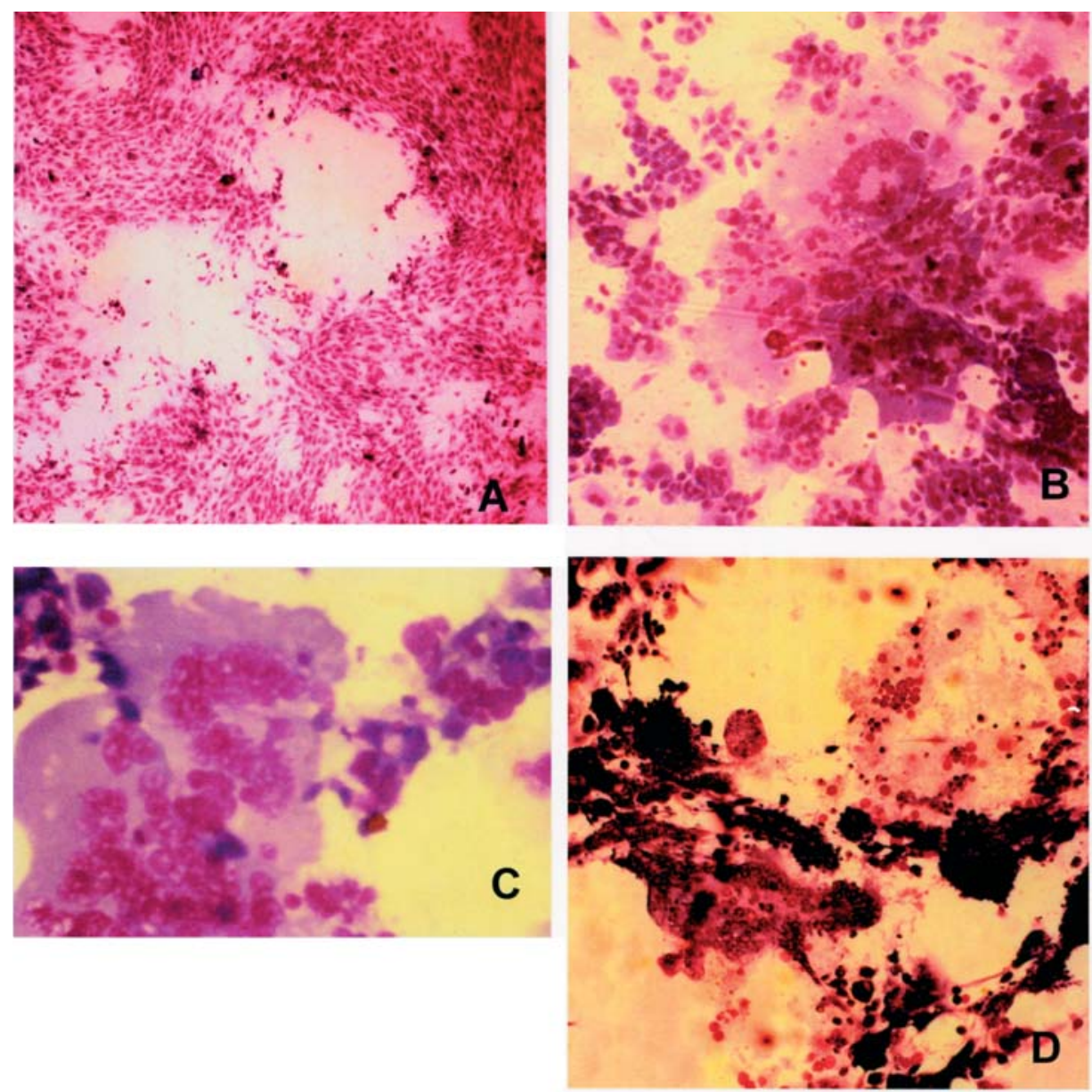

Figure 6. A, Vesicular stomatitis virus (VSV) infecting mouse embryo cells: cytotoxicity by prompt formation of plaques. B and C, In mouse leukemia virusharboring transformed mouse embryo cell cultures, which are defective in interferon production and resistant to exogenous interferon (crude preparation of IFN from NDV-infected mouse brain made in the 1960s), instead of prompt induction of plaques, syncytia are formed by the fusion of infected cells, which persist. D, Syncytia disintegrate with 'oncolysis' after several days. Original microphotographs preserved from the 1960s (70,71).

such a candidate in the human host), such a clinical trial could possibly be initiated. However, if the oncolytic virus is apathogenic because of immunological control of the host over it, immunosuppressive episodes consequential to chemotherapy may allow persistence of non-neutralized virus in the host, or restore viral virulence. Monoclonal antibodies, lympho- 
or cytokines and small molecular enzyme (kinase) inhibitors targeting oncoproteins are prime candidates for combination with virotherapy.

At the authors' Institution NDV oncolysates were administered either with subcutaneous low dose IFN- $\alpha 2 b$, or IL-2 or GM-CSF. Recent controversies concerning IL-2 administration in these settings $(75,76)$, suggest that the IL-2 arm be suspended (even though no harmful effects were as yet noted). One must presume that IL-2 may mobilize not only immune $\mathrm{T}$ and $\mathrm{NK}$ but also $\mathrm{T}_{\mathrm{REG}}$ cells. In view of this notion, the vaccine may be administered with low dose cyclophosphamide. However, in a pilot clinical trial at the authors' Institution (unpublished data) in the era when antiemetic drugs were not yet readily available, patients refused to continue taking orally cyclophosphamide prior to vaccinations due to its nauseating side effects. Further, during an open discussion at the 19th Conference of the International Society for Biotherapy of Cancer in 2004 in San Francisco, in answering a question from the senior author, Dr Don Morton stated that his melanoma vaccine, when co-administered with cyclophosphamide, did not show increased efficacy.

As to IFN- $\alpha$ and GM-CSF, there is cooperation between GM-CSF-secreting vaccines and IFN- $\alpha(39,40)$ as GM-CSF recruits and induces maturation of DC. IFN- $\alpha$ breaks 'tolerance to self', and while it may induce autoimmune complications, in patients with melanoma it also induces vitiligo (77). Building on the fact that chemotherapeuticals induce apoptotic or autophagic deaths of tumor cells, at the authors' Institution considerations are given to a clinical trial in which patients with cutaneous-subcutaneous metastatic tumors (melanoma, kidney carcinoma) would be treated with direct intratumoral injections of cytotoxic agents (thioTEPA, vincristine/vinblastine, dacarbazine, cisplatin, oncolytic virus) and the site of inoculation would be circum-infiltrated with GM-CSF, the expectation being that mature DC thus attracted to the site would upload and or intrinsically process tumor antigens for cross-presentation to $\mathrm{T}$ cells. In order to expand reactive $\mathrm{T}$ cell clones, the patients would receive subcutaneous injections of IL-2 in the range of 5 million units daily for 10 days (78). The procedure would be repeated at several tumor sites (if available). The inoculated sites would be fine needle-aspirated to analyze the composition of the cellular reaction thus mobilized. If an anti-tumor immune reaction could thus be induced loco-regionally, it may expand to exert systemic efficacy.

Glioblastoma. At the authors' Institution, a chemoimmunotherapy protocol for glioblastoma multiforme (GMF) has been formulated but not yet initiated [(79); Sinkovics JG, et al, Proc 10th World Congress Advances Oncology, Crete, Greece, Int J Mol Med 16 (Suppl): 62, abs. 331, 2005]. GMF cells are susceptible in vitro to oncolysis by NDV and lovastatin intensifies this effect (Horvath JC, manuscript in preparation). Patients with GMF would be vaccinated postoperatively with autologous NDV oncolysate; the efficacy of NDV oncolysate therapy in this tumor has been reported (80). Radiotherapy to the brain and temozolomide will be accepted as standard therapy. Either TIL or LAK cells would be collected from the vaccinated patients and adoptive immune lymphocyte therapy would be given with expanded clones of these lymphocyte populations either intravenously or directly into the tumor bed through an Ommaya reservoir. It should be ascertained that the lymphocyte population to be infused contains or is cloned for CTL reactive to autologous GMF cells in vitro. Adoptive immune lymphocyte therapy for GMF (79) should be given with low dose subcutaneous IL-2 administration (5 million IU daily for 10 days).

However, in adoptive immunotherapy, the resident lymphoid cell populations of the recipient antagonize the infused lymphocytes and greatly reduce their efficacy. This set back may be avoided by the depletion of the resident lymphocyte population before the infusion of immune lymphocytes (tumor-infiltrating lymphocytes, TIL, or lymphokineactivated killer LAK cells). Very effective depletion of the resident lymphocyte population can be achieved by the administration of fludara and/or cyclophosphamide $(81,82)$. Unfortunately, these chemotherapeuticals do not exert strong anti-tumor effects in cases of melanoma or glioblastoma, while their immunosuppressive side effects may invite lifethreatening infectious complications. In order to avoid these complications, the authors' Institutions would have utilized temozolomide for the depletion of the patient's resident lymphocyte population before the infusion of the autologous CTL clones. Due to financial considerations (lack of financial support and denial of reimbursement for NDV oncolysate vaccines and/or immune lymphocyte adoptive therapy by the health maintenance organizations, the HMOs), the authors' cancer immunotherapy laboratory, one of the last bastions of effective but 'old-fashioned' cancer immunotherapy, at the Cancer Institute, St. Joseph's Hospital, Tampa, FL, ceases its services as of June 2006 and this new glioblastoma protocol remains in suspense.

\section{Discussion}

Human tumor vaccines. This modality of treatment received some adverse comments in the recent literature from those who used specific peptide antigens as tumor vaccines, but favor adoptive lymphocyte therapy (83) and from those who never used any tumor vaccines (84). Indeed, tumor vaccines used with therapeutic intentions against established large tumor burdens practically always fail to induce immune reactions complex and strong enough for the rejection of such tumors. Some good results prematurely reported in Germany with DC vaccines (kidney carcinoma) had to be withdrawn. However, when the tumor burden is surgically reduced and the vaccine works against micrometastases, chances are much better for a clinical response. In case of chemotherapy, the burden of sensitive tumors is reduced; however chemotherapy-resistant tumors show unexpectedly good response to a second course of the same chemotherapy given after tumor-specific vaccination.

The empire strikes back. In the clinical setting of postoperative vaccination aimed at the eradication of micrometastases, tumor measurements to document the response are seldom possible. Here, the primary tumor already switched to the production of neoangiogenesis inhibitors (angiostatins, endostatins) in order to suppress its metastases, which are in the early stages of neoangiogenesis induction by VEGF or basic fibroblast growth factor (bFGF) production, either within the 
young tumor or in its microenvironment (85). The response is read years later by statistical comparisons of stratified, prospectively randomized vaccinated and non-vaccinated patients. In these cases, the combination of tumor vaccines (including viral oncolysates or oncolytic viruses) with targeted molecular therapy for the suppression of oncogenic and neoangiogenesis pathways in the occult metastases left behind after the removal of the established large primary tumor(s) offers itself for new clinical trials. Indeed, IFN- $\alpha$ should be considered in these combinations, if for no other reason than its suppressive effect on the $\mathrm{bFGF/Int} \mathrm{neoangiogenesis} \mathrm{induction}$ system (86).

For vaccinations against metastatic tumors, the combination of tumor vaccines with chemotherapeuticals appear to be obligatory in view of the data recently generated (87) and in a great part but not completely reviewed in this report. Here, the exact measurement of tumor sizes and its comparison between groups of differently treated patients is possible and provides evidence-supported results.

The mechanisms by which a tumor cell defends itself against its eradication are almost inexhaustible. One of the most ostentatious displays of such activity is the conversion of the FasL $\rightarrow$ FasR death domain pathway into an experimentally proven autocrine-paracrine growth circuit discovered in the authors' laboratory in human melanoma cells and probably based (experimentally not yet proven) on a newly formed 'fusion oncoprotein' receptor constructed by the two broken and thereafter mis-united chromosomes that normally encode the FasR and the granulocyte colony stimulatory factor receptor (G-CSF-R). Upon capturing FasL by the extracellular FasR, the pathway conducted by the intracellular G-CSF-R induces cell mitoses $(29,30$; Horvath JC, et al, Proc 89th Annual Meeting American Association Cancer Research, New Orleans, LA, 39: 584, abs. 3971, 1998). While neuroblastoma cells utilize tumor necrosis factor for an autocrine-paracrine growth loop (88), not only melanoma cells, but also glioblastoma cells expropriated the FasL $\rightarrow$ FasR pathway for mitosis induction diverting its physiological role in apoptotic cell death into a cell growth circuit (89). In the era of molecular medicine, the door that had been closed so long for 'no entrance', now may allow admission (90).

\section{Acknowledgments}

The senior author is grateful for the support and supervision of his work at The University of Texas M.D. Anderson Hospital from 1959-1979, to Heads of the Department of Medicine, Drs C.D. Howe and C.C. Shullenberger; to staff physician medical oncologists Drs Carl Plager and Nicholas Papadopoulos; to the fellows and resident physicians assigned to the MelanomaSarcoma Service, Department of Medicine for patient care and excellent clinical work; and to the technicians and medical technologists of the Section of Clinical Tumor Virology and Immunology, Department of Medicine, for meticulous laboratory work; their names are listed in the cited publications in this article and elsewhere in the literature. The clinical and laboratory works carried out at The University of Texas M.D. Anderson Hospital in the 1970 s by the senior author and cited in this report were supported by applied for, reviewed and Surveillance Committee-approved grants from the Kelsey-
Leary Foundation, the Barnhardt Fund, the Dr C.D. Howe Fund, the American Cancer Society Institutional Grant, the Don \& Sybill Harrington Foundation and the Baker \& Taylor Drilling Company, both of Amarillo, TX; sincere gratitude is expressed herein for this support. The authors express their gratitude to their outstanding collaborators at St. Joseph's Hospital's Cancer Institute's Cancer Research Laboratory: Dr Marianna Szabo-Szabari, Dr Andrea Horak, technicians Pamela Brown, Alison Knapp, Toon Kham, Michael Sorace and Vivian Vega; and to board-certified oncology nurses Cynthia Crumpton, RN and Mary Pritchard, RN for exemplary and individualized patient care.

\section{References}

1. Russ M: Questioning conventional oncology. An interview with cancer activist. Ralph W. Moss, PhD. Altern Complement Ther 7: 21-26, 2001.

2. Moss RW: The grand illusion of chemotherapy. Deutsche Zeitschr Onkol 33: 15-18, 2001.

3. Schirrmacher V: Antitumor immune memory and its activation for control of residual tumor cells and improvement of patient survival. A new concept derived from translational research with the virus-modified tumor vaccine ATV-NDV. In: Viral Therapy of Human Cancers. Sinkovics JG and Horvath JC (eds). Marcel Dekker, New York, pp481-531, 2005.

4. Sinkovics JG, Györkey F, Kusyk C and Siciliano MJ: Growth of human tumor cells in established cultures. Methods Cancer Res XIV: 243-323, 1978.

5. Sinkovics JG: Viral oncolysates as human tumor vaccines. Int Rev Immunol 7: 259-287, 1991.

6. Lindenmann $\mathrm{J}$ and Klein PA: Immunological aspects of viral oncolysis. Springer Verlag, New York, pp1-84, 1967.

7. Sinkovics JG: Progressive development of viral therapy of human cancers. In: Viral Therapy of Human Cancers. Sinkovics JG and Horvath JC (eds). Marcel Dekker, New York, pp1-147, 2005.

8. Gröschel D, Sinkovics JG and Rodriguez V: Project CP/cp2: the limulus test for detection of endotoxin in Gram-negative sepsis in cancer patients. Research Report 1974-1976. The University of Texas Cancer Center M.D. Anderson Hospital, Houston. University of Texas Press, Austin, pp221-225, 1976.

9. Sinkovics JG: Project M27/gm 15. Immunotherapy of cancer by immunization with cultured tumor cells. In: Research Report (Sept 1975-Aug 1977). The University of Texas M.D. Anderson Hospital and Tumor Institute, Houston. University of Texas Press, Austin, pp330-331, 1978.

10. Sinkovics JG, Plager C, McMurtrey MJ, Papadopoulos NE, Combs S, Romero JJ and Romsdahl MM: Adjuvant chemotherapy for malignant melanoma. In: Neoplasm Immunity Experimental and Clinical. Crispen RG (ed). Elsevier NorthHolland, New York, Amsterdam, pp481-519, 1980.

11. Sinkovics JG, Plager C and McMurtrey MJ: Chemoimmunotherapy: basic principles and clinical examples. In: Basis for Cancer Therapy 2. Advances in Medical Oncology, Research and Education. Moore M (ed). Proc 12th Int Cancer Congress, Buenos Aires, Argentina. Pergamon Press, Oxford, New York, pp121-129, 1979.

12. Sinkovics JG, Papadopoulos N and Plager C: Viral oncolysates for the immunotherapy of human tumors. In: Advances in Comparative Leukemia Research 1981. Yohn DS and Blakeslee JR (eds). Elsevier BioMedical, New York, Amsterdam, pp613-615, 1982.

13. Sinkovics JG: Complete remissions lasting over three years in adult patients treated for metastatic sarcoma. In: Tumor Progression. Crispen RG (ed). Elsevier North-Holland, New York, Amsterdam, pp315-331, 1980.

14. Sinkovics JG, Thota H, Loh KK, Gonzalez F, Campos LT, Romero JJ, Kay HD and King D: Prospectives for immunotherapy for human sarcomas. In: Cancer Chemotherapy Fundamental Concepts and Recent Advances. 19th Annual Clinical Conference, The University of Texas M.D. Anderson Hospital, Houston, Year Book Medical Publisher, Chicago, pp417-443, 1975.

15. Sinkovics JG: Immunotherapy with viral oncolysates for sarcoma. JAMA 237: 869, 1977. 
16. Sinkovics JG, Plager $\mathrm{C}$ and Romero J: Immunology and immunotherapy of patients with sarcomas. In: Neoplasm Immunity: Solid Tumor Therapy. Crispen RG (ed). Franklin Institute Press, Philadelphia, pp211-219, 1977.

17. Sinkovics JG, Campos LT, Kay HD, Loh KK, Gonzalez JR, Cabiness JR, Ervin F and Gyorkey F: Immunological studies with human sarcomas: effects of immunization and chemotherapy on cell- and antibody-mediated immune reactions. In: Immunological Aspects of Neoplasia. Williams \& Wilkins, Baltimore, pp367-401, 1975.

18. Sinkovics JG: A reappraisal of cytotoxic lymphocytes in human tumor immunology. In: Cancer Biology and Therapeutics. The 1st H. Lee Moffitt Cancer Center Conference. Cory JG and Szentivanyi A (eds). Plenum Press, New York, London, pp225-253, 1986.

19. Sinkovics JG and Horvath JC: Human natural killer cells: a comprehensive review. Int J Oncol 27: 5-47, 2005.

20. Freedman RS, Edwards CL, Bowen JM, Lotzova E, Katz R, Lewis E, Atkinson N and Carsetti R: Viral oncolysates in patients with advanced ovarian cancers. Gynecol Oncol 29: 337-347, 1988.

21. Sinkovics JG, Cabiness JR and Shullenberger CC: Disappearance after chemotherapy of blocking serum factors as measured in vitro with lymphocytes cytotoxic to tumor cells. Cancer 30: 1428-1437, 1972.

22. Harris J, Sengar D, Stewart T and Hyslop D: The effect of immunosuppressive chemotherapy on immune function in patients with malignant disease. Cancer 37 (Suppl 2): 1058-1069, 1976.

23. Emens LA and Jaffee EM: Leveraging the activity of tumor vaccines with cytotoxic chemotherapy. Cancer Res 65: 8059-8064, 2005.

24. Lake RA and Robinson BW: Immunotherapy and chemotherapy a practical partnership. Nat Rev Cancer 5: 397-405, 2005.

25. Coral S, Sigalotti M, Altomonte M, Engelsberg A, Colizzi F, Cattarossi I, Maraskovsky E, Jager E, Seliger B and Maio M: 5-Aza-2-deoxycytidine-induced expression of functional cancer testis antigens in human renal cell carcinoma: immunotherapeutic implications. Clin Cancer Res 8: 2690-2695, 2002.

26. Demaria S, Volm M, Shapiro RL, Yee HT, Oratz R, Formenti SC, Muggia F and Symmans WF: Development of tumor-infiltrating lymphocytes in breast cancer after neoadjuvant paclitaxel chemotherapy. Clin Cancer Res 7: 3025-3033, 2001.

27. Kawasaki K, Akashi S, Shimazu R, Yoshida T, Miyake K and Nishijima M: Mouse toll-like receptor 4MD-2 complex mediates lipopolysaccharide-mimetic signal transduction by taxol. J Biol Chem 275: 2251-2254, 2000.

28. Thomas A, Santarsiero I, Lutz E, Armstrong TD, Chen YC, Huang LQ, Laheru DA, Goggins M, Hruban RH and Jaffee EM: Mesothelin-specific $\mathrm{CD} 8^{+} \mathrm{T}$ cell responses provide evidence of in vivo cross-priming by antigen-presenting cells in vaccinated pancreatic cancer patients. J Exp Med 200: 297-306, 2004.

29. Sinkovics JG: Malignant lymphoma arising from natural killer cells: report of the first case in 1970 and newer developments in the FasL $\rightarrow$ FasR system. (erratum: as in the MS the FasR is CD95). Acta Microbiol Immunol Hungar 44: 295-306, 1997.

30. Sinkovics JG and Horvath JC: Virological and immunological connotations of apoptotic and anti-apoptotic forces in neoplasia. Int J Oncol 19: 473-488, 2001

31. Yang S and Haluska F: Treatment of melanoma with 5fluorouracil or dacarbazine in vitro sensitizes cells to antigenspecific CTL lysis through perforin-granzyme and Fas-mediated pathways. J Immunol 172: 4599-4608, 2004.

32. Li W and Bertino J: Fas-mediated signaling enhances sensitivity of human soft tissue sarcoma cells to anticancer drugs by activation of p38 kinase. Mol Cancer Ther 14: 1343-1348, 2002.

33. Gasser S, Orsulic S, Brown EJ and Raulet DH: The DNA damage pathway regulates innate immune system ligands of the NKG2D receptor. Nature 436: 1186-1190, 2005.

34. Gasser S and Raulet DH: The DNA damage response arouses the immune system. Cancer Res 66: 3959-3962, 2006.

35. Binder RJ and Srivastava PK: Peptids chaperoned by heat-shock proteins are a necessary and sufficient source of antigen in the cross-priming of CD8 $8^{+}$T cells. Nat Immunol 6: 593-599, 2005.

36. Hernandez J, Aung S, Marquardt K and Sherman LA: Uncoupling of proliferative potential and gain of effector function by CD8 T cells responding to self antigens. J Exp Med 196: 323-333, 2002.

37. Marzo AI, Lake RA, Lo D, Sherman L, McWilliam A, Nelson D, Robinson BW and Scott B: Tumor antigens are constitutively presented in the draining lymph nodes. J Immunol 162: 5838-5845, 1999.
38. Van der Most RG, Currie A, Robinson BW and Lake RA: Cranking the immunologic engine with chemotherapy: using context to drive tumor antigen cross-presentation towards useful antitumor immunity. Cancer Res 66: 601-604, 2006.

39. Radvanyi LG, Banerjee A, Weir M and Messner H: Low levels of interferon- $\alpha$ induce CD86 (B7.2) expression and accelerates dendritic cell maturation from human peripheral blood mononuclear cells. Scand J Immunol 50: 499-509, 1999

40. Prell RA, Li B, Lin JM, van Roey M and Jooss K: Administration of IFN- $\alpha$ enhances the efficacy of a granulocyte macrophage colony stimulating factor-secreting tumor cell vaccine. Cancer Res 65: 2449-2456, 2005

41. Correale P, Aquino A, Giuliani A, Pellegrini M, Micheli L, Cusi MG, Nencini C, Petrioli R, Prete SP, De Vecchis L, Turriziani M, Giorgi G, Bonmassar E and Francini G: Treatment of colon and breast carcinoma cells with 5-fluorouracil enhances expression of carcinoembryonic antigen and susceptibility to HLA-A*02.01 restricted CEA-peptide-specific cytotoxic T cells in vitro. Int J Cancer 104: 437-445, 1993.

42. Zaks TZ and Rosenberg SA: Immunization with a peptide epitope (p369-377) from HER2/neu leads to peptide-specific cytotoxic T lymphocytes that fail to recognize HER2/neu $u^{+}$tumors. Cancer Res 58: 4902-4908, 1998.

43. Byrd-Leifer C, Block E, Takeda K, Akira S and Ding A: The role of MydD88 and TLR4 in the LPS-mimetic activity of taxol. Eur J Immunol 31: 2448-2457, 2001

44. Nowak A, Robinson B and Lake R: Gemcitabine exerts a selective effect on the humoral immune response: implications for combination chemo-immunotherapy. Cancer Res 62: 2353-2358, 2002.

45. Machiels J-P, Reilly R, Emens I, Ercolini AM, Lei RY, Weintraub D, Okoye FI and Jaffee EM: Cyclophosphamide, doxorubicin and paclitaxel enhance the anti-tumor immune response of GM-CSF-secreting whole cell vaccines in HER2/neu tolerized mice. Cancer Res 61: 3689-3697, 2001.

46. Ercolini A, Machiels J-P, Chen YC, Slansky JE, Giedlen M, Reilly RT and Jaffee EM: Identification and characterization of the immunodominant rat HER2/neu MHC class I epitope presented by spontaneous mammary tumors from HER $2 /$ neu transgenic mice. J Immunol 170: 4273-4280, 2003.

47. Eralp Y, Wang X, Wang J, Maughan MF, Polo JM and Lachman LB: Doxorubicin and paclitaxel enhance the antitumor efficacy of vaccines directed against HER2/neu in a mouse mammary carcinoma model. Breast Cancer Res 6: 275-283, 2004.

48. Schiavoni G, Mattei F, Di Puchio T, Santini SM, Bracci L, Belardewlli F and Proietti E: Cyclophosphamide induces type I interferon and augments the number of CD44 $4^{\text {high }} \mathrm{T}$ lymphocytes in mice: implications for strategies of chemoimmunotherapy of cancer. Blood 95: 2024-2030, 2000.

49. Nigan A, Ysacavone R, Zahurak M, Johns CM, Pardoll DM and Proietti E: Immunomodulatory properties of antineoplastic drugs administered in conjunction with GM-CSF-secreting cancer cell vaccines. Int J Cancer 12: 161-170, 1998.

50. Harris JE, Ryan L, Hoover HC Jr, Stuart RK, Oken MM, Benson AB III, Mansour E, Haller DG, Manola J and Hanna MG Jr: Adjuvant active specific immunotherapy for stage II and III colon cancer with an autologous tumor cell vaccine. J Cin Oncol 18: $14-57,2000$

51. Arlen PM, Gulley JL, Parker C, Skarupa L, Pazdur M, Panicalli D, Beetham P, Tsang KY, Grosenbach DW, Feldman J, Steinberg SM, Jones E, Chen C, Marte J, Schlom J and Dahut W: A randomized phased I study of concurrent docetaxel plus vaccine versus vaccine alone in metastatic androgen-independent prostate cancer. Clin Cancer Res 12: 1260-1269, 2006.

52. Andersen MH, Østergard Pedersen L, Becker JC and Straten PT: Identification of a cytotoxic $\mathrm{T}$ lymphocyte response to the apoptosis inhibitor protein survivin in cancer patients. Cancer Res 61: 869-872, 2000

53. Vonderheide RH, Domchek SM, Schultze JL, George DJ, Hoar KM, Chen DY, Stephans KF, Masutomi K, Loda M, Xia Z, Anderson KS, Hahn WC and Nadler LM: Vaccination of cancer patients against telomerase induces functional antitumor $\mathrm{CD}^{+}$ T lymphocytes. Clin Cancer Res 10: 828-839, 2004.

54. Antonia SJ, Mirza N, Fricke I, Chiappori A, Thompson P, Williams N, Bepler G, Simon G, Janssen SW, Lee JH, Menander K, Chada DS and Gabrilovich DI: Combination of p53 cancer vaccine with chemotherapy in patients with extensive stage small cell lung cancer. Clin Cancer Res 12: 878-887, 2006. 
55. Gribben JG, Ryan DP, Boyajian R, Urban RG, Hedley ML, Beach K, Nealon P, Matulonis U, Campos S, Gilligan TD, Richardson PG, Marshall B, Neuberg D and Nadler LM: Unexpected association between induction of immunity to the universal tumor antigen CYP1B1 and response to next therapy. Clin Cancer Res 11: 4430-4446, 2005.

56. Stewart TH, Hollinshead AC, Harris JE, Belanger R, Crepeau A, Hooper GD, Sachs HJ, Klaassen DJ, Hirte W, Rapp E, Crook AF, Orizaga M, Sengar DP and Raman S: Immunochemotherapy of lung cancer. Ann NY Acad Sci 277: 436-466, 1976.

57. Yu JS, Wheeler CJ, Zeltzer PM, Ying H, Finger DN, Lee PK, Yong WH, Incardona F, Thompson RC, Riedinger MS, Zhang W, Prins RM and Black KL: Vaccination of malignant glioma patients with peptide-pulsed dendritic cells elicits systemic cytotoxicity and intracranial T-cell infiltration. Cancer Res 61: 842-847, 2001.

58. Wheeler CJ, Das A, Liu G, Yu JS and Black KL: Clinical responsiveness of glioblastoma multiforme to chemotherapy after vaccination. Clin Cancer Res 10: 5316-5326, 2004.

59. Lapis K and Tímár J: Role of elastin-matrix interactions in tumor progression. Semin Cancer Biol 12: 209-217, 2002.

60. Tímár J, Lapis K, Dudás J, Sebestyén A, Kopper L and Kovalszky I: Proteoglycans and tumor progression: Janus-faced molecules with contradictory functions in cancer. Semin Cancer Biol 12: 173-186, 2002.

61. Sinkovics JG: The predictive value of tissue culture and xenograft assays. In: Viral Therapy of Human Cancers. Sinkovics JG and Horvath JC (eds). Marcel Dekker, New York, pp320-396, 2005.

62. Curiel TJ, Coukos G, Zou L, Alvarez X, Cheng P, Mottram P, Evdemon-Hogan M, Conejo-Garcia JR, Zhang L, Burow M, Zhu Y, Wei S, Kryczek I, Daniel B, Gordon A, Myers L, Lackner A, Disis ML, Knutson KL, Chen L and Zhou W: Specific recruitment of regulatory $\mathrm{T}$ cells in ovarian carcinoma fosters immune privilege and predicts reduced survival. Nat Med 10: 942-949, 2004.

63. Shevach EM: Fatal attraction: tumors beckon regulatory $\mathrm{T}$ cells. Nat Med 10: 900-901, 2004.

64. Muller AJ and Prendergast GC: Marrying immunotherapy with chemotherapy: why say IDO? Cancer Res 65: 8065-8068, 2005.

65. Muller AJ, Duhadaway JB, Donover PS, Sutano-Ward E and Prendergast GC: Inhibition of indoleamine 2,3-dioxygenase, an immunoregulatory target of the cancer suppression gene Bin1, potentiates cancer chemotherapy. Nat Med 11: 312-319, 2004.

66. Belardelli F, Ferrantini M, Parmiani G, Schlom J and Garaci E: International meeting on cancer vaccines: how can we enhance efficacy of therapeutic vaccines? Cancer Res 64: 6827-6830, 2004.

67. Cassel WA, Murray DR and Olkowski ZL: Newcastle disease virus oncolysate in the management of stage III malignant melanoma. In: Viral Therapy of Human Cancers. Sinkovics JG and Horvath JC (eds). Marcel Dekker, New York, pp677-689, 2005.

68. Horvath JC: Newcastle disease virus: its oncolytic properties. In: Viral Therapy of Human Cancers. Sinkovics JG and Horvath JC (eds). Marcel Dekker, New York, pp533-574, 2005.

69. Sinkovics J: Die Grundlagen der Virusforschung. Budapest, Hungary: Verlag der ungarischen Akademie der Wissenschaften, Budapest, Hungary, pp3-420, 1956

70. Sinkovics JG, Groves GF and Howe CD: Actions of interferon in tissue cultures harboring mouse leukemia virus. Experientia 24: $927-928,1968$

71. Sinkovics JG and Howe CD: Superinfection of tumors with viruses. Experientia 25: 733-734, 1969.

72. Linardakis E, Bateman A, Phan V, Ahmed A, Gough M, Olivier K, Kennedy R, Errington F, Harrington KJ, Melcher A and Vile R: Enhancing the efficacy of a weak allogeneic melanoma vaccine by viral fusogenic membrane glycoproteinmediated tumor cell-tumor cell fusion. Cancer Res 62: 5495-5504, 2002.

73. Bateman A, Harrington KJ, Kottke T, Ahmed A, Melcher AA, Gough MJ, Linardakis E, Riddle D, Dietz A, Lohse CM, Strome S, Peterson T, Simari R and Vile RG: Viral fusogenic membrane glycoproteins kill solid tumor cells by nonapoptotic mechanisms that promote cross presentation of tumor antigen by dendritic cells. Cancer Res 62: 6566-6578, 2002.
74. Errington F, Bateman A, Kottke T, Thompson J, Harrington K, Merrick A, Hatfield P, Selby P, Vile R and Melcher A: Allogeneic tumor cells expressing fusogenic membrane glycoproteins as a platform for clinical cancer immunotherapy. Clin Cancer Res 12: $1333-1341,2006$.

75. Andersen MH, Gehl J, Reker S, Geertsen P, Becker JC and thor Stratem P: Concomitant adminstration of interleukin-2 during therapeutic vaccination against cancer: the good, the bad, or the evil. J Clin Oncol 23: 5265-5267, 2005.

76. Singluff CL, Chianese-Bullock K and Yamschikov G: Interleukin-2 effects deserve further study: a need for better understanding of biology and of optimal dose regimens. J Clin Oncol 23: 5267-5268, 2005.

77. Gogas H, Ioannovich J, Dafni U, Stavropoulou-Giokas C, Frangia K, Tsoutos D, Panagiotou P, Polyzos A, Papadopoulos O, Stratigos A, Markopoulos C, Bafaloukos D, Pectasides D, Fountzilas G and Kirkwood JM: Prognostic significance of autoimmunity during treatment of melanoma with interferon. $\mathrm{N}$ Engl J Med 354: 709-711, 2006.

78. Sinkovics JG and Horvath JC: Virus therapy of human cancers. Melanoma Res 13: 431-432, 2003.

79. Sinkovics JG: Glioblastoma multiforme. In: Viral Therapy of Human Cancers. Sinkovics JG and Horvath JC (eds). Marcel Dekker, New York, pp410-425, 2005.

80. Steiner HH, Bonsanto MM, Beckhove P, Brysch M, Gelewtneky K, Ahmadi R, Schule-Freyer R, Kremer P, Ranaie G, Matejic D, Bauer H, Kiessling M, Kunze S, Schirrmacher V and Herold-Mende C: Antitumor vaccination of patients with glioblastoma multiforme: a pilot study to assess feasibility, safety and clinical benefit. J Clin Oncol 22: 4272-4281, 2004

81. Rosenberg SA and Dudley ME: Cancer regression in patients with metastatic melanoma after the transfer of autologous antitumor lymphocytes. Proc Nat Acad Sci USA 101: 14639-14645, 2004.

82. Dudley ME, Wunderlich JR, Yang JC, Sherry RM, Topalian SL, Restifo NP, Royal RE, Kammula U, White DE, Mavroukakis SA, Rogers LJ, Gracia GJ, Jones SA, Mangiameli DP, Pelletier MM, Gea-Banacloche J, Robinson MR, Berman DM, Filie AC, Abati A and Rosenberg SA: Adoptive cell transfer therapy following non-myeloablative but lymphodepleting chemotherapy for the treatment of patients with refractory metastatic melanoma. J Clin Oncol 23: 2346-2357, 2005

83. Rosenberg SA, Yang JC and Restifo NP: Cancer immunotherapy: moving beyond current vaccines. Nat Med 10: 909-915, 2004.

84. Bodey B, Bodey B Jr, Siegel SE and Kaiser HE: Failure of cancer vaccines: the significant limitations of this approach to immunotherapy. Anticancer Res 20: 2665-2676, 2000.

85. O'Reilly MS, Holmgren L, Shing Y, Chen C, Rosenthal RA, Moses M, Lane WS, Cao Y, Sage EH and Folkman J: Angiostatin: a novel angiogenesis inhibitor that mediates the suppression of metastases by a Lewis lung carcinoma. Cell 79: 315-328, 1994.

86. Sinkovics JG: Interferons: antiangiogenesis agents. Can J Infect Dis 3 (Suppl): 128-132, 1992.

87. Terando A and Mulé JJ: On combining antineoplastic drugs with tumor vaccines. Cancer Immunol Immunother 52: 680-685, 2003.

88. Goillot E, Combaret V, Ladenstein R, Baubet D, Blay JY, Philip T and Favrot MC: Tumor necrosis factor as an autocrine growth factor for neuroblastoma. Cancer Res 52: 3194-3200, 1992.

89. Shinohara H, Yagita H, Ikawa Y and Oyaizu N: Fas drives cell cycle progression in glioma cells via extracellular signal-regulated kinase activation. Cancer Res 60: 1766-1772, 2000.

90. Sinkovics JG: On the threshold of the door of 'no admittance'. In: The Immunologic Revolution: Facts and Witnesses. Friedman H and Szentivanyi A (eds). CRC Press, Boca Raton, pp241-286, 1994. 